their blood supply is extensive it arises from vessels normally supplying the stomach, and bleeding is reduced by carrying the dissection towards the midline origin of these vessels. A thoraco-abdominal incision as used in the second case, is well suited to this lateral to medial dissection.

The ability to recognize these tumours from their gross appearance is important, for the pathologist may not be able to make a diagnosis from frozen sections of the tumour. Even in prepared histological material differentiation between benign and malignant smooth muscle tumours of this type is difficult. The clinical progress of such patients is the best indicator of the pathological nature of the original tumour, if a histological diagnosis of malignancy was not made on the operation specimen. Both the patients described here are alive and well 1 year after resection with no evidence of recurrence.

It is of interest that the first patient noted an increase in his exercise tolerance following the removal of his tumour. This was confirmed by significant improvement in respiratory function tests performed postoperatively.

That excision of these large exogastric tumours was possible and successfully performed in two patients, whom by age and respiratory insufficiency respectively carried a greater than normal operative risk supports and underlines the plea for total excision of these tumours.

\section{Acknowledgments}

We thank Mr C. J. B. Murray and Mr W. W. Slack under whose care these patients were admitted, for permission to publish these case reports and for their help with the preparation of this paper.

\section{References}

Herlinger, H. (1966) The recognition of exogastric tumours. British Journal of Radiology, 39, 25.

Skandalakis, J.E., Gray, S.W. \& Shepherd, D. (1960) Smooth muscle tumors of the stomach. International Abstracts of Surgery, 110, 209.

\title{
Survival of candida septicaemia treated with amphotericin B
}

\author{
A. B. S. Mitchell \\ M.B., M.R.C.P. \\ G. HosKING \\ M.B., L.R.C.P.
}

\author{
I. T. Magrath \\ M.B., M.R.C.P.
}

C. P. FARThing

M.B., M.R.C.Path.

West London Hospital, Charing Cross Group of Hospitals, London, W.6

\begin{abstract}
Summary
Candida albicans septicaemia occurred in an alcoholic woman who had severe hepatic dysfunction, and was further debilitated by multiple cardiac arrests, prolonged artificial ventilation, bronchopneumonia and $P$. aeruginosa septicaemia. She received broad spectrum antibiotics and corticosteroids, and needed prolonged intravenous cannulation. In vitro, a specific defect was demonstrated in her cell-mediated immune response to candida antigens. Examination of her serum showed normal immunoglobulins, and an adequate agglutination titre to these antigens.

Amphotericin B (800 mg intravenously over 19 days) was administered, and she survived. Hypokalaemia, anaemia, and peripheral neuropathy complicated
\end{abstract}

therapy, and thrombophlebitis of a cannulated peripheral vein necessitated a vena caval catheter. There was no significant deterioration of renal function.

Toxic effects of other drugs were encountereddeafness following kanamycin, an encephalopathy when blood levels of carbenicillin were boosted by probenecid, and cardiac arrest when diazepam and phenobarbitone were administered to control an epileptic fit and delirium tremens. Prolonged intravenous cannulation was complicated by staphylococcal septicaemia.

A year later she died of peritonitis. Chronic pancreatitis was complicated by ascites, which became infected by $E$. coli. No residual $C$. albicans infection was found at necropsy. 


\section{Case report}

A barmaid was admitted to the West London Hospital in 1966, and again in 1968, suffering from alcoholic gastritis. On the second occasion there was evidence also of liver dysfunction and a peripheral neuropathy. Abstinence from alcohol was only temporary after each admission, despite psychiatric care. Barbiturate habituation developed.

She was re-admitted in May 1970, aged 46 years, in hepatic coma. Intravenous rehydration, neomycin by nasogastric tube, and enemata led to recovery of consciousness after $48 \mathrm{hr}$. Hypokalaemia (serum potassium $1.9 \mathrm{mEq} / \mathrm{l}$ ) developed, and was corrected by intravenous therapy. On the fourth day after admission she had a grand mal epileptic fit, terminated by intravenous diazepam. Delirium tremens ensued and required sedation with intramuscular phenobarbitone and intravenous diazepam (total doses: 400 and $40 \mathrm{mg}$ respectively). While still sedated $36 \mathrm{hr}$ after the fit, asystolic cardiac and respiratory arrest occurred. External cardiac massage and ventilation restored sinus rhythm. After 300 $\mathrm{mEq}$ sodium bicarbonate had been infused, the arterial blood $\mathrm{pH}$ was normal. Inhalation of gastric contents was suspected, so hydrocortisone $(600 \mathrm{mg}$ daily) and cephaloridine ( $2 \mathrm{~g}$ daily) were administered. She did not regain consciousness, and within $48 \mathrm{hr}$ became pyrexial. There were signs of bronchopneumonia, and, despite being ventilated with pure oxygen, her arterial blood $\mathrm{Po}_{2}$ was $63 \mathrm{mmHg}$. Multiple ventricular extrasystoles were suppressed by intravenous lignocaine, but a further cardiac arrest again required external cardiac massage. Purulent sputum grew Ps. aeruginosa, E. coli, Strep. pneumoniae, and Candida albicans on culture. Hydrocortisone was discontinued, and the antibiotic regime changed to gentamicin $(160 \mathrm{mg}$ intramuscularly daily) and cloxacillin ( $2 \mathrm{~g}$ intravenously daily). After the second cardiac arrest she remained areflexic with fixed dilated pupils for 3 days. Two days after these reflexes returned, spontaneous respiration recurred. Tracheal oedema caused by the endotracheal tube gave rise to respiratory distress. To combat this, hydrocortisone ( $300 \mathrm{mg}$ daily) was administered for the 3 days during which she was weaned from the ventilator.

She remained pyrexial, although her chest became clinically and radiologically clear, and her sputum non-purulent. On the seventh day of receiving gentamicin and cloxacillin, an indwelling urinary catheter was removed, and she had a rigor with hypotension. Bacteraemic shock was suspected, blood was taken for culture, the antibiotics were stopped and kanamycin ( $1 \mathrm{~g}$ intramuscularly) was given. Within $3 \mathrm{hr}$ she complained of deafness, which lasted for $12 \mathrm{hr}$. Cephaloridine was substituted for kanamycin. Ps. aeruginosa was present in all blood culture bottles taken on three successive days, and was also present in the sputum. Candida albicans was recovered from urine, sputum and a throat swab. Carbenicillin $(30 \mathrm{~g}$ intravenously daily) was commenced. Two days later probenecid ( $2 \mathrm{~g}$ daily) was added, and within $24 \mathrm{hr}$ she became disoriented, remaining so until $24 \mathrm{hr}$ after this drug was discontinued 5 days later. She became apyrexial 5 days after carbenicillin was started. This state lasted for only 1 day; her fever then rose higher than before $\left(103-104^{\circ} \mathrm{F}\right)$. Colistin (3 mega-units intravenously daily) was added to the carbenicillin, and she was transfused with blood because her haemoglobin level had fallen to $9.0 \mathrm{~g} / 100$ $\mathrm{ml}$. Buccal thrush was treated with topical gentian violet; $C$. albicans was cultured from mouth swabs.

Her fever persisted. C. albicans then grew in all four blood culture bottles taken over 2 days, and in a urine culture. Amphotericin B was started at a dose of $0.25 \mathrm{mg} / \mathrm{kg}$ body weight, increased over a week to $1.0 \mathrm{mg} / \mathrm{kg}$ body weight. The $C$. albicans was shown to be sensitive to $1.0 \mu \mathrm{g} / \mathrm{ml}$ amphotericin B in vitro. As thrombophlebitis of the cannulated vein interrupted administration of the drug, a catheter was inserted into the inferior vena cava, and the infusion continued for a total of 19 days (total dose $800 \mathrm{mg}$ ). Before amphotericin B therapy was started, her serum potassium was $3.3 \mathrm{mEq} / \mathrm{l}$, blood urea $15 \mathrm{mg} / 100 \mathrm{ml}$, and plasma creatinine $0.6 \mathrm{mg} / 100 \mathrm{ml}$. Despite oral potassium supplements, the serum potassium concentration fell to $1.9 \mathrm{mEq} / \mathrm{l}$ while the drug was given, and rose to within normal limits 10 days after the drug was discontinued; the dose of potassium supplement remained unchanged. The blood urea rose to $30 \mathrm{mg} / 100 \mathrm{ml}$, and the plasma creatinine to $0.9 \mathrm{mg} / 100 \mathrm{ml}$. The haemoglobin concentration was $10.5 \mathrm{~g} / 100 \mathrm{ml}$ when amphotericin B therapy was started, and fell to $8 \cdot 3 \mathrm{~g} / 100 \mathrm{ml}$. She was transfused with 4 pints of blood raising the haemoglobin concentration to $14.0 \mathrm{~g} / 100 \mathrm{ml}$ at the end of therapy. Ten days after amphotericin B was started (dose by then $330 \mathrm{mg}$ ), she complained of paraesthesiae in her hands and feet. On admission to hospital her ankle jerks had been absent. This remained the only abnormal neurological sign in her limbs despite the continuing symptom. There was no nausea or vomiting. Five days after starting amphotericin B (dose by then $120 \mathrm{mg}$ ), C. albicans failed to grow in blood cultures.

She remained pyrexial throughout the administration of amphotericin B. The drug was stopped when she had a rigor. The caval catheter was removed, and cephaloridine started. Culture of swabs from the groin incision, the tip of the catheter, and of the blood all grew Staph. aureus which was resistant to penicillin and tetracycline but sensitive to cephaloridine, cloxacillin and fusidic acid on in vitro testing. The antibiotic was changed to cloxacillin, which was 
continued for 10 days. She remained apyrexial during the last 3 weeks in hospital.

When seen in the clinic after discharge from hospital, she had again reverted to drinking alcohol. The paraesthesiae had disappeared and she felt well. Investigation of her immune mechanisms were performed 4 months after leaving hospital. A moderate diffuse increase in gammaglobulin was shown on cellulose acetate electrophoresis. Quantitative determination of her immunoglobulins gave the following concentrations expressed in $\mathrm{mg} / 100 \mathrm{ml}$ : IgG 1050 (normal range 500-1500), IgA 350 (normal range 130-430), IgM 170 (normal range 50-710). An agglutination titre of $1: 128$ was found against whole formalized cells of $C$. albicans (type A) using the technique of Winner (1955). No precipitins were found against a cell-wall extract of the same type of candida using the technique of Pepys et al. (1968), nor were any precipitins demonstrated against a somatic extract of a similar candida using the technique of Stallybrass (1964). Lymphocyte transformation was studied by measuring the incorporation of $3 \mathrm{HTd}$ into DNA after 5 days of culture stimulated with a culture filtrate antigen of $C$. albicans, PPD and PHA. There was marked transformation in response to PPD and PHA (uptake was 39.5 and 48.5 times that of unstimulated cells) but the candida antigen did not stimulate transformation. Inhibition of peripheral blood leucocyte migration did not occur with the candida antigen (method of Federlin et al., 1971) and supernatant fluid from lymphocytes cultured with candida filtrate did not contain any activity inhibitory to peripheral leucocyte migration.

She received further psychiatric help in an attempt to cure her addiction. She declined institutional care, and her consumption of alcohol increased. In June 1971 she was re-admitted because she had become jaundiced. Ascites was present but no signs of peritonism. Serum amylase normal, serum albumin $3.5 \mathrm{~g} / 100 \mathrm{ml}$. Two days later she developed signs of pelvic peritonitis, which became generalized. She died following a laparotomy. E. coli were cultured from the peritoneal fluid.

Necropsy confirmed the generalized peritonitis and cirrhosis of the liver. There were no signs of portal hypertension. The spleen was enlarged due to occlusion of the splenic vein by organized thrombus, a common complication of chronic pancreatitis (Leger, Lenriot \& Lemaigre, 1968) which was present. No perforated viscus or localized infective lesion was found to explain the peritonitis which was presumably due to 'spontaneous' infection of ascitic fluid. This had accumulated in association with chronic pancreatitis (Schindler et al., 1970). No residual $C$. albicans infection was present.

\section{Discussion}

Acute disseminated (septicaemic) candidosis carries a grave prognosis in adults (Table 1). It has long been recognized that recovery from candida fungaemia could occur in children without specific therapy (Vince, 1959), but this has been reported in few adults (Table 1). This cannot be anticipated in a patient who is clinically septicaemic.

C. albicans is commonly found in many sites of the body, but only occasionally gives rise to disseminated infection. A complex of factors would then appear to be operative (Zimmerman, 1955), and these were present in this patient. An underlying state of poor resistance was provided by hepatic cirrhosis and failure, prolonged coma, artificial respiration, and bacterial septicaemia. An ecological disturbance waso brought about by multiple antibiotics and corti costeroids, and prolonged venous cannulation proto vided a portal of entry for infection. Investigation of her immune mechanisms gave results which suggest a specific defect in cell-mediated immunity, as measured by in vitro correlates, to the culture filtrate antigen of $C$. albicans. Although in normal individuals measurements of in vitro parameters of cellmediated immunity give variable results (Faux \& Maini, 1971, personal communication), there seems little doubt that a generalized defect in cell-mediated immunological responsiveness is an important predisposing factor to generalized candida infection (Folb \& Trounce, 1970). In addition, this patient failed to develop in vitro evidence of cell-mediated immunity to candida some months after elimination of the infective agent, and this suggests that splittolerance to candida antigens developed because of

TABLE 1. The number of survivors, and their treatment, from published series of adults from whose blood candida was cultured

\begin{tabular}{|c|c|c|c|}
\hline \multicolumn{2}{|c|}{ Patients } & \multirow[t]{2}{*}{ Treatment of survivors } & \multirow[t]{2}{*}{ Authors } \\
\hline Total & Survivors & & \\
\hline 27 & 2 & 2-amphotericin B & $\begin{array}{l}\text { Winner \& Hurley (1964) } \\
\text { (review of literature) }\end{array}$ \\
\hline 12 & 4 & $\begin{array}{l}\text { 1-amphotericin B } \\
3 \text {-nil }\end{array}$ & Ellis \& Spivak (1967) \\
\hline 10 & 2 & $2-$ nil & Salter \& Zinneman (1967) \\
\hline 6 & 1 & $1-$ nil & Kozinn et al. (1969) \\
\hline
\end{tabular}


ness at the time of the infection-a similar situation to the development of tolerance to antigens administered during 6-mercaptopurine administration (Hoyer et al., 1962; Schwarz \& Dameshek, 1960). A preexisting specific deficiency in 'lymphokine' production (Dumonde \& Maini, 1971) could have been causally related to the candida septicaemia, but there is no means of verifying such a deficiency in this patient. Agglutinins to candida are not affected by immunosuppression, and are probably less important as a protective mechanism against generalized candida infection than cell-mediated immunity (Folb \& Trounce, 1970).

One of the few drugs of established value in the treatment of disseminated candidosis is amphotericin B. Its use is limited by its toxic side-effects, but these should not prevent it being used when indicated (Winner, 1966). Nephrotoxicity is the most common serious side-effect, with azotaemia, diminished glomerular filtration rate (Butler et al., 1964), and hypokalaemia, with perhaps nephrocalcinosis (McCurdy, Frederic \& Elkington, 1968). The only nephrotoxic effect in this case was a reduction in the serum potassium concentration. This was soon reversed after amphotericin $\mathbf{B}$ was discontinued. Anaemia due to erythropoietic suppression, another common toxic side-effect (Brandriss et al., 1964), was produced, and required blood transfusion. Peripheral neuropathy is an uncommon toxic effect (Haber \& Joseph, 1962; Staal, Mechelse \& de Leeuw, 1963). As the paraesthesiae developed during therapy with amphotericin B and a period of enforced abstention from alcohol, and disappeared after the drug was discontinued despite the resumption of alcohol intake this is likely to represent a toxic effect of the drug on peripheral nerves already damaged by alcohol. Thrombophlebitis commonly interferes with therapy, and was overcome by the insertion of a vena caval catheter (Newcomer et al., 1959). Nausea, vomiting, shaking chills and fever are the most frequent sideeffects (Utz \& Treger, 1959), but only the last of these occurred in this case, and was not troublesome.

In a complex clinical situation involving polypharmacy toxic effects of particular drugs are difficult to distinguish. Transient deafness followed an injection of kanamycin and probably reflects the ototoxic effect of this drug, perhaps a summation effect with the related antibiotic, gentamicin. The encephalopathy, which developed when carbenicillin blood levels were boosted by probenecid, probably represents an unusual effect of this drug, analogous to that occurring with penicillin in high dosage (New $\&$ Wells, 1965). This has been reported when carbenicillin was given to patients with impaired renal function (Hoffman \& Bullock, 1970). The isolated epileptic fit soon after admission was due possibly to withdrawal of barbiturates (Gardner, 1967), or the generally poor state of immunological responsivealcohol (Brain \& Walton, 1969); and the cardiac arrest might have resulted from the use of diazepam and phenobarbitone (Bell, 1969), particularly in association with alcohol withdrawal (Golbert et al., 1967). Intravenous potassium was being given at the time of the arrest, but at an infusion rate of less than $10 \mathrm{mEq} / \mathrm{hr}$. Septicaemia is a recognized hazard of prolonged intravenous cannulation. The recovery after having been comatose with fixed dilated pupils for 3 days emphasizes the difficulty of diagnosing brain death (Lancet, 1970). The effects of alcoholism, and its relapse rate, are apparent.

\section{Acknowledgments}

We should like to thank Professor H. I. Winner for advice on the management of this case, and for encouraging us to report it. Dr J. A. Faux and Dr R. N. Maini kindly supplied the candida antigen, and Dr Maini advised on the investigation of cell-mediated immunity. Dr B. Partridge measured the candida agglutinins and precipitins, and $\mathrm{Dr} \mathrm{A}$. Walker assayed the immunoglobulins. We should like to thank Dr A. Morton Gill for permission to publish details of the case under his care.

\section{References}

BeLL, D.S. (1969) Dangers of treatment of status epilepticus with diazepam. British Medical Journal, 1, 159.

Brain M. \& Walton, J.N. (1969) In: Diseases of the Nervous System, (Ed. by M. Brain and J. N. Walton), 7th edn., p. 688. Oxford University Press, London.

Brandriss, M.W., Sheldon, M.W., Moores, R. \& StohlMAN, F. (1964) Anaemia induced by amphotericin B. Journal of the American Medical Association, 189, 663.

Butler, W.T., Bennett, J.E., Alling, D.W., Wertlake, P.T. \& HiLl, G.J. (1964) Nephrotoxicity of amphotericin B. Annals of Internal Medicine, 61, 175.

DumONDE, D. \& MAINI, R.N. (1971) The clinical significance of mediators of cellular immunity. Clinical Allergy, 1, 123.

Ellis, C.A. \& SpIVAK, M.L. (1967) The significance of candidosis. Annals of Internal Medicine, 67, 511.

Federlin, K., Maini, R.N., Russell, A.R. \& Dumonde D.C (1971) A micro-method of peripheral leucocyte migration. Journal of Clinical Pathology, 24, 533.

Folb, P.I. \& TrounCE, J.R. (1970) Immunological aspects of candida infection complicating steroid and immunosuppressive drug therapy. Lancet, ii, 112.

GARDNER, A.J. (1967) Withdrawal fits in barbiturate addicts, Lancet, ii, 337.

Golbert, T.M., Sanz, C.J., Rose, H.D. \& LeitschuK, T.H. (1967) Comparative evaluation of treatments of alcohol withdrawal syndromes. Journal of the American Medical Association, 201, 99.

Haber, R.W. \& JoSEPH, M. (1962) Neurological manifestations after amphotericin B therapy. British Medical Journal, 1, 230.

Hoffman, T.A. \& Bullock, W.E. (1970) Carbenicillin therapy of Pseudomonas and other Gram-negative bacillary infections. Annals of Internal Medicine, 73, 165.

Hoyer, J.M., Hoyer, L.W., Good, R.A. \& Condie, R.M. (1962) The effect of 6-mercaptopurine on delayed hypersensitivity in guinea pigs. Journal of Experimental Medicine, 116, 679.

Kozinn, P.J., Taschdjian, C.L., Seelig, M.S., Leona, C. \& Teitler, A. (1969) Diagnosis and therapy of systemic candiasis. Sabouraudia, 7, 98.

Lancet (1970) Reversible death, 2, 1172. 
Leger, L., Lenriot, J.P. \& Lemaigre, G. (1968) L'hypertension et la stase portales segmentaires dans les pancréatites chroniques. Journal de Chirurgie (Paris), 95, 599.

McCurdy, D.K., Frederic, M. \& Elkington, J.R. (1968) Renotubular acidosis due to amphotericin B. New England Journal of Medicine, 278, 124.

NeW, P.S. \& Wells, C.E. (1965) Cerebral toxicity associated with massive intravenous penicillin therapy. Neurology, 15, 1053.

Newcomer, V.D., Sternberg, T.H., Wright, E.T. \& REISNER, R.M. (1959) Current status of amphotericin B in the treatment of systemic fungus infections. Journal of Chronic Disease, 9, 353.

Pepys, J., FaUX, J.A., Longbottom, J.L., McCarthy, D.S. \& HARGREAVES, F.E. (1968) Candida albicans precipitins in respiratory disease in man. Journal of Allergy, 41, 305.

SAlTER, W. \& ZinNemaN, H.N. (1967) Bacteremia and candida septicaemia. Minnesota Medicine, 50, 1489.

Schindler, S.C., Schaefer, J.W., Hull, D. \& Griffen, W.O. JR. (1970) Chronic pancreatic ascites. Gastroentero$\log y, 59,453$.

Schwarz, R. \& DAMEsheK, W. (1960) The effects of 6mercaptopurine on homograft reaction. Journal of Clinical Investigation, 39, 952.
StaAl, A., Mechelse, K. \& De Leeuw, B. (1963) Neurologische complicatie by toediening van een fungicied antibioticum. Nederlands Tïdschrift voor Geneeshuade, 107, 2276.

Stallybrass, F.C. (1964) Candida precipitins. Journal of Pathology and Bacteriology, 87, 89.

UTZ, J.P. \& TREGER, A. (1959) The current status of chemotherapy of systemic fungal diseases. Annals of Internal Medicine, 51, 1220.

VINCE, S. (1959) Generalised endogenous mycoses in childhood. Medical Journal of Australia, 46, 145.

WINNER, H.I. (1955) A study of Candida albicans agglutinins in human serum. Journal of Hygiene, 53, 509.

Winner, H.I. (1966) Symposium on Candida Infections (Ed. by $\mathbf{H}$. I. Winner and R. Hurley). Livingstone, Edinburgh and London.

WinNer, H.I. \& HuRley, R. (1964) Candida albicans. Churchill, London.

ZIMMERMAN, L.E. (1955) Fatal fungal infections complicating other diseases. American Journal of Clinical Pathology, 25, 46.

\title{
Myopathy from E-aminocaproic acid: a second case
}

\author{
JOHN R. BENNETT \\ M.D., M.R.C.P.
}

\section{Gastro-Intestinal Unit, Hull Royal Infirmary, Kingston-upon-Hull}

EPSILON-AMINOCAPROIC acid (EACA) is an antifibrinolytic agent which inhibits the activation of plasminogen to plasmin (Alkjaersig, Fletcher \& Sherry, 1959). Its main therapeutic use is in the arrest of bleeding when abnormal fibrinolytic mechanisms are present (Sweeney, 1965). Because of suggestions that fibrinolysis in the colonic mucosa might be abnormal in ulcerative colitis (Kwaan, Cocco \& Mendeloff, 1964). EACA has been used to control excessive bleeding in this condition with apparent success (Nilsson, Anderson \& Bjorkman, 1966; Salter \& Read, 1970). There is a high incidence of side-effects from EACA, such as nausea, diarrhoea, giddiness and faintness, but few serious toxic effects have been encountered other than possible thrombosis. However, one patient who developed extensive muscle necrosis during EACA treatment for periodic oedema has been described (Korsan-Bengsten et al., 1969) and this report is of myopathy due to EACA in a patient with ulcerative colitis.

\section{Case report}

A male clerk developed frequent, watery, bloodstained diarrhoea at the age of 32, and initially improved on self-administered herbal treatment. He was first seen in relapse after 2 years' illness when he was acutely ill, with an oral temperature of $104^{\circ} \mathrm{F}$. There was oral ulceration and sigmoidoscopy showed the rectal mucosa to be thickened, granular, friable and bleeding. Barium enema was normal and initial investigations gave these results: $\mathrm{Hb}, 12 \cdot 2 \mathrm{~g} / 100 \mathrm{ml}$; serum sodium, $133 \mathrm{mEq} / 1$; potassium, $3.9 \mathrm{mEq} / 1$; chloride, $100 \mathrm{mEq} / \mathrm{l}$; serum mucoproteins, 187 $\mathrm{mg} / 100 \mathrm{ml}$. Microscopy and culture of faeces revealed no parasites or pathogenic bacteria.

Treatment with intramuscular corticotrophin gel $80 \mathrm{U}$ daily, oral sulphasalazine $1 \mathrm{~g}$ 6-hourly, hydrocortisone enemata $100 \mathrm{mg}$ daily, with intravenous fluid and electrolyte replacement (1 September 1970) caused early improvement and he kecame afebrile within 4 days. Nevertheless, diarrhoea with copious visible bleeding persisted and after 2 weeks' treatment the rectal mucosa still looked acutely inflamed sigmoidoscopically. EACA (as Epsikapron syrup) $6 \mathrm{~g}$ every $6 \mathrm{hr}$ was commenced on 14 September, and a week later (21 September) azathioprine $100 \mathrm{mg}$ daily was added to his treatment; subsequently both the frequency of diarrhoea and quantity of bleeding diminished. Corticotrophin was gradually withdrawn and stopped on 16 October, but he remained on 